\title{
Glucocorticoids decrease body weight and food intake and inhibit appetite regulatory peptide expression in the hypothalamus of rats
}

\author{
XIAO-YAN LIU ${ }^{1 *}$, JIAN-HUA SHI ${ }^{2 *}$, WEN-HUA DU ${ }^{2}$, YAN-PING FAN ${ }^{2}$, XIAO-LEI HU ${ }^{2}$, CHEN-CHEN ZHANG $^{2}$, \\ HUAN-BAI XU ${ }^{2}$, YAN-JUN MIAO ${ }^{2}$, HAI-YAN ZHOU ${ }^{2}$, PING XIANG ${ }^{2}$ and FENG-LING CHEN ${ }^{1}$ \\ ${ }^{1}$ Department of Endocrinology, No. 3 People's Hospital Affiliated with Shanghai Jiao Tong University \\ School of Medicine, Shanghai 201900; ${ }^{2}$ Department of Endocrinology, Affiliated Hospital \\ of Bangbu Medical College, Bangbu, Anhui 233004, P.R. China
}

Received April 13, 2011; Accepted June 9, 2011

DOI: $10.3892 /$ etm.2011.292

\begin{abstract}
The aim of the present study was to investigate the effects of glucocorticoids (GCs) on appetite and gene expression of the hypothalamic appetite regulatory peptides, neuropeptide Y (NPY), agouti-related protein (AGRP) and cocaine and amphetamine-regulated transcript (CART), in non-obese and obese rats. Both non-obese and obese rats were randomly assigned to three groups: normal saline, low- and high-dose GC groups (NSG, LDG and HDG, respectively), which received an intraperitoneal injection with normal saline $(0.2 \mathrm{ml} / 100 \mathrm{~g})$ or hydrocortisone sodium succinate at 5 and $15 \mathrm{mg} / \mathrm{kg}$, respectively, for 20 days. The expression levels of NPY, AGRP and CART mRNA in the hypothalamus were measured by real-time quantitative PCR. Non-obese and obese rats were found to undergo weight loss after $\mathrm{GC}$ injection, and a higher degree of weight loss was observed in the HDG rats. The average and cumulative food intakes in the obese and nonobese rats injected with high-dose GC were lower compared to that in the NSG $(\mathrm{p}<0.05)$. mRNA expression levels of the orexigenic neuropeptides, NPY and AGRP, and the anorexigenic neuropeptide, CART, were significantly lower in the HDG than levels in the NSG for both the obese and non-obese rats $(\mathrm{p}<0.05)$. GC treatment decreased appetite and body weight, induced apparent glucolipid metabolic disturbances and hyperinsulinemia, while down-regulated mRNA expression levels of the orexigenic neuropeptides, NPY and AGRP, and anorexigenic neuropeptide, CART, in the hypothalamus in the rats. The mechanism which induces this neuropeptide expression requires further study.
\end{abstract}

Correspondence to: Dr Feng-Ling Chen, Department of Endocrinology, No. 3 People's Hospital Affiliated to Shanghai Jiao Tong University School of Medicine, 80\# MoHe Road, Shanghai 201900, P.R. China

E-mail: fengling_chen@hotmail.com

*Contributed equally

Key words: glucocorticoids, rat, weight, neuropeptide Y, food intake, agouti-related protein

\section{Introduction}

The balance between energy intake and expenditure is of critical importance to maintain normal body weight, and obesity is the most common state associated with energy imbalance. At present, studies on the mechanisms of obesity involve many factors, and the hypothalamus is a 'hot spot', since it plays a key role in the regulation of appetite and energy homeostasis. Previous studies found that appetite and body weight decreased after damage to the lateral hypothalamic area (LHA) and increased after damage to the ventromedial hypothalamic nucleus (VMH). In view of these findings, a dual center theory was suggested, i.e., the 'LHA hunger center' and 'VMH repletion center' (1). Recent studies have reported that specific neural pathways and several neuropeptide signaling pathways control energy metabolism homeostasis, which are crucial to the regulation of appetite.

Neuropeptide Y (NPY) is an important neurotransmitter in the hypothalamus which regulates appetite and energy homeostasis, and is closely related to the activities of many other appetite regulatory factors (2-6). The mRNA expression level of NPY and its quantity of release are increased during fasting, while they are decreased after food intake. Central administration of NPY has been found to stimulate food intake, reduce energy expenditure and brown fat lysis, inhibit sympathetic nervous activity and thyroid axis activity, and increase serum leptin, insulin and cortisol levels (7-9).

NPY gene knockout mice exhibited decreased refeeding in response to 24 or $48 \mathrm{~h}$ fasting (10), although they had normal body weight and adipose tissue. It is possible that a compensation mechanism exists, and other signaling pathways aid to partially up-regulate appetite, for example, agouti-related protein (AGRP).

The endogenous melanocortin receptor antagonist AGRP and NPY coexist in the arcuate nucleus (ARC), and both exert orexigenic effects (11-14). The AGRP mRNA level is up-regulated in fasting. The AGRP C-terminal fragment inhibits the anorectic effect of $\alpha$-MSH and increases nighttime food intake. AGRP not only alters food intake, but also decreases energy expenditure. Central administration of AGRP and transgenic animals overexpressing AGRP both result in increased food intake $(15,16)$. Chronic intracerebroventricular 
(i.c.v.) administration of AGRP was found to increase food intake, body weight and body adiposity, resulted in a profound suppression of brown adipose tissue uncoupling protein 1 (BAT UCP-1) and decreased plasma TSH, and these metabolic effects were independent of food intake $(17,18)$.

Cocaine and amphetamine-regulated transcript (CART) peptides play a role in the control of food intake by the brain, and exhibit functional interaction with NPY. CART and $\alpha-\mathrm{MSH}$ coexist in the ARC, and are also expressed in nerve cells in the LHA and paraventricular nucleus (PVN). Administration of the CART peptide fragment (i.c.v.) was found to inhibit feeding in rats both at night and in response to fasting. Injection of the CART peptide before NPY attenuated the increase in feeding caused by the injection of NPY alone (11-14).

Elevated circulating level of glucocorticoids (GCs) or hypersensitivity to these hormones has long been thought to play a role in the development and maintenance of obesity. In obese humans, particularly those with abdominal obesity, increased production of GCs, increased concentrations of tissue GC and GC receptors, and over-responsiveness of the hypothalamic-pituitary-adrenal (HPA) axis to different neuropeptides and stress tasks have been reported. Clinically, patients treated with GCs or who exhibit GC over-secretion consistently show increased body weight. Animals administered GCs (i.c.v.) reportedly display increased food intake and body weight $(19,20)$, while other studies have reported that GCs inhibit food intake and body weight.

Thus, paradoxical findings exist on the effect of GC on food intake, body weight and appetite regulatory peptides in rats. In the present study, we investigated the effect of a GC (hydrocortisone sodium succinate, 20-day continuous intraperitoneal infusion) on food intake, body weight and the hypothalamic appetite regulatory peptides, NPY, AGRP and CART, in non-obese and obese rats.

\section{Materials and methods}

Materials. The Superscript II RT kit was purchased from Invitrogen (USA). The RNase-free DNase kit was purchased from Qiagen (Germany). The PCR primers were synthesized by the Shanghai Sangon Factory (Shanghai, China). TaqDNA polymerase, isopropyl alcohol and dehydrated alcohol were also purchased from the Shanghai Sangon Factory. One hundred and twenty-five healthy male SPF SD rats were purchased from the Experimental Animal LLC (license no. 2003-0003; Shanghai, China). Hydrocortisone sodium succinate was purchased from Tianjin Biochemtory Pharmaceutical Factory (batch no. 20060314; Tianjin, China).

Animals and diets. One hundred and twenty-five healthy male SFP SD rats, weight 180-200 g, were randomly assigned into groups of 38 chow-diet rats (CD; containing water $9.2 \%$, crude protein $22.1 \%$, crude fat $5.28 \%$, crude ash content $5.20 \%$, crude cellulose $4.12 \%$, no nitrogen extract $52.0 \%$, calcium $1.24 \%$, phosphorus $0.92 \%$, calcium/phosphorus 1.35 , lysine $1.34 \%$, metione + cystine $0.72 \%$; total energy content $352 \mathrm{kcal} / 100 \mathrm{~g}$ ), and 87 high-fat diet rats [HF; containing fat $20 \%$, granulated sugar $4 \%$, whole milk powder (Yili Brand) $2 \%$, cholesterol $1 \%$, chleolate $0.5 \%$, basic animal feeds $73 \%$; total energy content
Table I. Primers used for real-time RT-PCR.

\begin{tabular}{|c|c|}
\hline Name (organism/Genbank) & Primers $\left(5^{\prime}-3^{\prime}\right)$ \\
\hline $\begin{array}{l}\beta \text {-actin } \\
\text { (rats/NM_031144) }\end{array}$ & $\begin{array}{l}\text { GACGGTCAGGTCATCACTATCG } \\
\text { ACGGATGTCAACGTCACACTTC }\end{array}$ \\
\hline $\begin{array}{l}\text { NPY } \\
\text { (rats/NM_012614) }\end{array}$ & $\begin{array}{l}\text { CAAGAGATCCAGCCCTGAGACA } \\
\text { CATCACCACATGGAAGGGTCTTC }\end{array}$ \\
\hline $\begin{array}{l}\text { AGRP } \\
\text { (rats/XM_574228; } \\
\text { AF_206017) }\end{array}$ & $\begin{array}{l}\text { GGCCATGCTGACTGCAATG } \\
\text { CGGTCTGCTGCTGTCTTGTTC }\end{array}$ \\
\hline $\begin{array}{l}\text { CART } \\
\text { (rats/NM_017110) }\end{array}$ & $\begin{array}{l}\text { GATGCGTCCCATGAGAAGGA } \\
\text { TCGGAATGCGTTTACTCTTGAG }\end{array}$ \\
\hline
\end{tabular}

$493 \mathrm{kcal} / 100 \mathrm{~g}$, made by Shanghai Experimental Animal LLC and stored at -20 to $4^{\circ} \mathrm{C}$ ]. All rats were provided with water (pH 2.5-2.8) and feed freely. After 80 days of HF feed, the rats with a body weight greater than the mean weight +1.5 standard deviations, and a Lee's index greater than the mean Lee's index +1.5 standard deviations, were characterized as obese. Rats fed the CD were characterized as non-obese. All animal handling procedures and the protocol were in accordance with the National Institutes of Health Guidelines for the Care and Use of Laboratory Animals.

GC treatment. Non-obese and obese rats were randomly assigned to a normal saline group (NSG; $0.2 \mathrm{ml} / 100 \mathrm{~g} /$ day), lowdose GC group (LDG; hydrocortisone sodium succinate $5 \mathrm{mg}$ / $\mathrm{kg}$ /day) or high-dose GC group (HDG; hydrocortisone sodium succinate $15 \mathrm{mg} / \mathrm{kg} /$ day), and received a peritoneal injection at 8:00 a.m. for 20 consecutive days (deviation $\leq 10 \mathrm{~min}$ ). Hydrocortisone sodium succinate was freshly prepared before the injection every day.

Observation index. Vitality, activity, fur, appetite, diachorema, weight, stem length (from nose to anus), Lee's index \{Lee's index $\left.=[\text { weight }(\mathrm{g}) / \text { stem length }(\mathrm{cm})]^{1 / 3} \times 10\right\}$, serum glucose and serum lipids were examined.

Sample preparation. Food and drink deprivation was carried out $\geq 8 \mathrm{~h}$, starting at 7:00-9:00 a.m. Serum samples were collected from the tail (to avoid hemolysis), stored for $30 \mathrm{~min}$ at room temperature, centrifuged at $5,000 \mathrm{rpm}$ for $20 \mathrm{~min}$ to separate serum, and then stored at $-80^{\circ} \mathrm{C}$.

Serology assay method. Serum glucose and lipids were detected by a fully automatic biochemistry assay instrument (Olympus AV2700).

Total RNA extraction and identification. Total RNA was extracted using TRIzol (Gibco/Brl) according to the manufacturer's instructions.

Real-time PCR. The primers used for real-time RT-PCR experiment were synthesized as shown Table I. Opticon Monitor 3 software was used to analyze the results, and thus obtained the $\mathrm{C}_{\mathrm{T}}$. The housekeeping gene $\beta$-actin was used as the control 
A

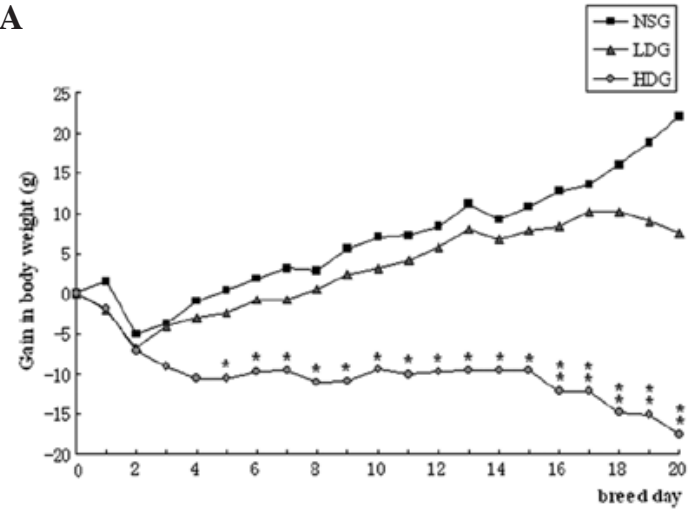

C

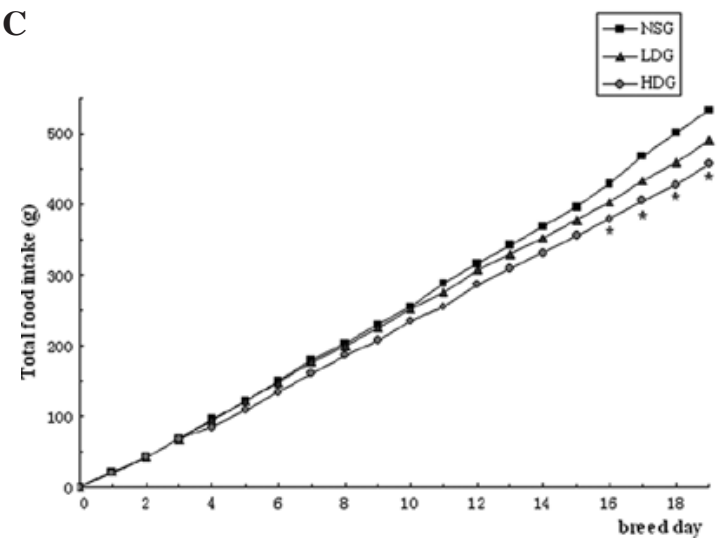

B

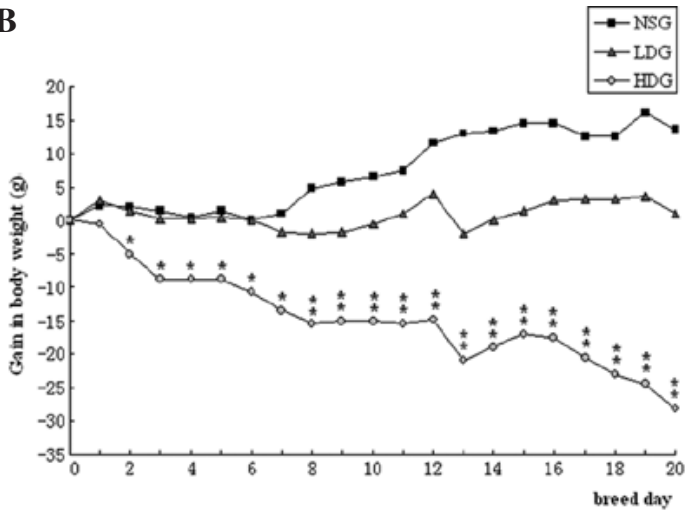

D

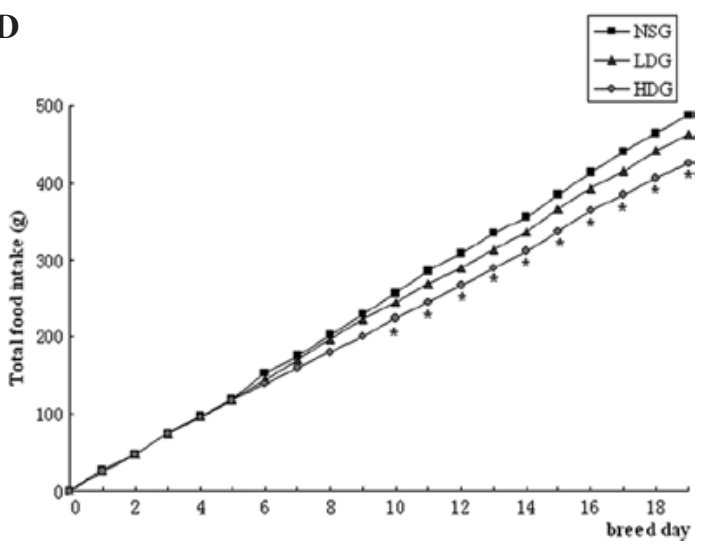

Figure 1. Effect of GC on body weight and cumulative food intake in rats. High-dose GC (15 mg/kg/day) reduced body weight in both (A) non-obese rats from the 5th day of injection and (B) obese rats from the 2nd day, and these differences lasted until the end of treatment. High-dose GC inhibited food intake in both (C) non-obese rats from the 16th day and (D) obese rats from the 10th day, and the significance of the effect lasted to the end of the treatment. After low-dose GC treatment ( $5 \mathrm{mg} / \mathrm{kg} / \mathrm{day})$, neither body weight nor cumulative food intake was significantly different from that of the NSG $\left({ }^{*} \mathrm{p}<0.05,{ }^{* *} \mathrm{p}<0.01\right)$. NSG, normal saline group; LDG, low-dose glucocorticoid group ( $5 \mathrm{mg} / \mathrm{kg} /$ day); HDG, high-dose glucocorticoid group (15 mg/kg/day).

to attain $\Delta \mathrm{C}_{\mathrm{T}}$ after verifying $\mathrm{C}_{\mathrm{T}}$. The difference between the treated and control groups was expressed as $2^{-\Delta \Delta \mathrm{C}_{\mathrm{T}}}$.

$\Delta \mathrm{C}_{\mathrm{T}}=\mathrm{C}_{\mathrm{T} \text { (target) }}-\mathrm{C}_{\mathrm{T}(\beta \text {-actin) }}$ and $\Delta \Delta \mathrm{C}_{\mathrm{T}}=\Delta \mathrm{C}_{\mathrm{T} \text { (treated) }}-\Delta \mathrm{C}_{\mathrm{T} \text { (control) }}$

Statistical methods. Measurement data are presented as the mean \pm standard error. The Student's t-test was used for comparisons between the means of two groups after homoscedasticity was verified by homogeneity test for variance with the SPSS Base 11.5 software package. A value of $\mathrm{p}<0.05$ was considered statistically significant.

\section{Results}

$G C$-related decrease in the body weight of the rats. The mean weight decreased by $25.69 \pm 23.05 \mathrm{~g}$ after high-dose GC treatment in the non-obese rats, while it increased by $5.08 \pm 30.68 \mathrm{~g}$ $(\mathrm{t}=4.09, \mathrm{p}<0.01)$ after normal saline treatment, while the body length did not exhibit any significant difference $(0.58 \pm 0.95$ vs. $0.54 \pm 0.54 \mathrm{~cm}, \mathrm{t}=0.56, \mathrm{p}>0.05)$. In the obese rats, the mean weight decreased by $33.07 \pm 30.01 \mathrm{~g}$ after high-dose GC treatment, while it increased by $12.00 \pm 30.08 \mathrm{~g}(\mathrm{t}=4.19$, $\mathrm{p}<0.01)$ after normal saline treatment, and the body length was unchanged $(0.68 \pm 1.22$ vs. $0.50 \pm 0.71 \mathrm{~cm}, \mathrm{t}=0.47, \mathrm{p}>0.05)$.

Rats in the LDG had no obvious difference in body weight or length change compared to rats in the HDG and NSG for either the non-obese or obese rats $(p>0.05)$.
The body weight of the non-obese rats after high-dose GC treatment was evidently decreased from the 5th day to the end of treatment compared to the NSG rats $(\mathrm{t}=2.08, \mathrm{p}<0.05)$, and the difference was significantly enhanced from the 16th day $(t=3.06, p<0.01)$ (Fig. 1A). For the obese rats, the decrease began from the 2 nd day $(\mathrm{t}=2.54, \mathrm{p}<0.05)$ and was augmented from the 8 th day $(t=4.53, p<0.001)$ (Fig. 1B). These results revealed that body weight decreased after high-dose GC treatment in both the non-obese and obese rats, and decreased earlier in the obese rats.

$G C$ decreases the appetite in the rats. To understand the possible mechanism of the weight decrease which occurred after the high-dose GC injection, the mean food intake in the rats was analyzed. In the non-obese rats the mean food intake was found to be significantly decreased after 20 days of continuous high-dose GC treatment compared to the mean food intake level in the NSG rats $(23.91 \pm 1.89 \mathrm{vs} .28 .02 \pm 3.22 \mathrm{~g} /$ day, $\mathrm{t}=3.85, \mathrm{p}<0.05)$, while there was no significant difference in food intake between the LDG and NSG rats $(25.61 \pm 4.52$ vs. $28.02 \pm 3.22 \mathrm{~g} / \mathrm{day}, \mathrm{t}=1.55, \mathrm{p}>0.05$ ) (Fig. 1C). In the obese rats, the mean food intake also decreased after high-dose GC treatment compared to the NSG rats $(22.64 \pm 2.86$ vs. $25.87 \pm 3.56 \mathrm{~g} / \mathrm{day}, \mathrm{t}=2.60, \mathrm{p}<0.05)$, and again there was no significant difference in mean food intake between rats in the LDG and NSG (24.64 \pm 2.95 vs. $25.87 \pm 3.56 \mathrm{~g} / \mathrm{day}, \mathrm{t}=0.95$, $\mathrm{p}>0.05$ ) (Fig. 1D). 
Table II. Effects of GC on serum glucose, lipids and insulin in rats.

\begin{tabular}{|c|c|c|c|c|c|c|}
\hline Group (N) & Glu (mmol/l) & $\mathrm{TG}(\mathrm{mmol} / \mathrm{l})$ & $\mathrm{CHO}(\mathrm{mmol} / \mathrm{l})$ & $\operatorname{LDL}(\mathrm{mmol} / \mathrm{l})$ & HDL (mmol/l) & $\mathrm{INS}(\mu \mathrm{IU} / \mathrm{ml})$ \\
\hline \multicolumn{7}{|c|}{ Non-obese rats } \\
\hline NSG (12) & $5.28 \pm 0.74$ & $1.02 \pm 0.26$ & $2.45 \pm 0.37$ & $0.44 \pm 0.09$ & $1.65 \pm 0.33$ & $19.42 \pm 2.90$ \\
\hline LDG (13) & $6.21 \pm 0.97^{\mathrm{a}}$ & $1.87 \pm 0.62^{c}$ & $3.10 \pm 0.81$ & $0.65 \pm 0.30^{\mathrm{a}}$ & $1.33 \pm 0.31^{\mathrm{a}}$ & $24.31 \pm 3.76^{\mathrm{b}}$ \\
\hline HDG (13) & $6.80 \pm 0.80^{c}$ & $2.12 \pm 0.61^{\mathrm{c}}$ & $3.70 \pm 1.25^{\mathrm{b}}$ & $0.80 \pm 0.14^{\mathrm{c}}$ & $1.16 \pm 0.26^{\mathrm{c}}$ & $38.58 \pm 5.38^{c}$ \\
\hline $\mathrm{F}$ & 10.19 & 14.50 & 6.00 & 10.10 & 8.52 & 72.16 \\
\hline p-value & $<0.001$ & $<0.001$ & $<0.01$ & $<0.001$ & $<0.01$ & $<0.001$ \\
\hline \multicolumn{7}{|l|}{ Obese rats } \\
\hline NSG (13) & $6.53 \pm 1.72$ & $1.67 \pm 0.73$ & $3.00 \pm 0.85$ & $0.93 \pm 0.18$ & $1.12 \pm 0.15$ & $33.56 \pm 3.12$ \\
\hline LDG (13) & $7.77 \pm 1.19^{\mathrm{a}}$ & $2.30 \pm 0.71$ & $3.79 \pm 0.86^{\mathrm{a}}$ & $1.73 \pm 0.94^{b}$ & $0.90 \pm 0.17^{\mathrm{b}}$ & $40.69 \pm 3.57^{c}$ \\
\hline HDG (14) & $8.16 \pm 0.87^{b}$ & $2.84 \pm 0.95^{\mathrm{b}}$ & $4.13 \pm 1.01^{\mathrm{b}}$ & $1.86 \pm 0.73^{b}$ & $0.86 \pm 0.16^{c}$ & $53.62 \pm 5.69^{c}$ \\
\hline $\mathrm{F}$ & 5.50 & 6.95 & 5.17 & 6.85 & 10.32 & 75.09 \\
\hline p-value & $<0.01$ & $<0.01$ & $<0.05$ & $<0.01$ & $<0.001$ & $<0.001$ \\
\hline
\end{tabular}

Glu, glucose; TG, triglycerides; CHO, total cholesterol; LDL, low-density lipoprotein; HDL, high-density lipoprotein, INS, insulin. NSG, normal saline group; LDG, low-dose glucocorticoid group (5 mg/kg/day); HDG, high-dose glucocorticoid group (15 mg/kg/day). ${ }^{2} \mathrm{p}<0.05$, ${ }^{\mathrm{b}} \mathrm{p}<0.01,{ }^{\mathrm{c}} \mathrm{p}<0.001$, both compared to NSG. Data are represented as the mean $\pm \mathrm{SE}$.

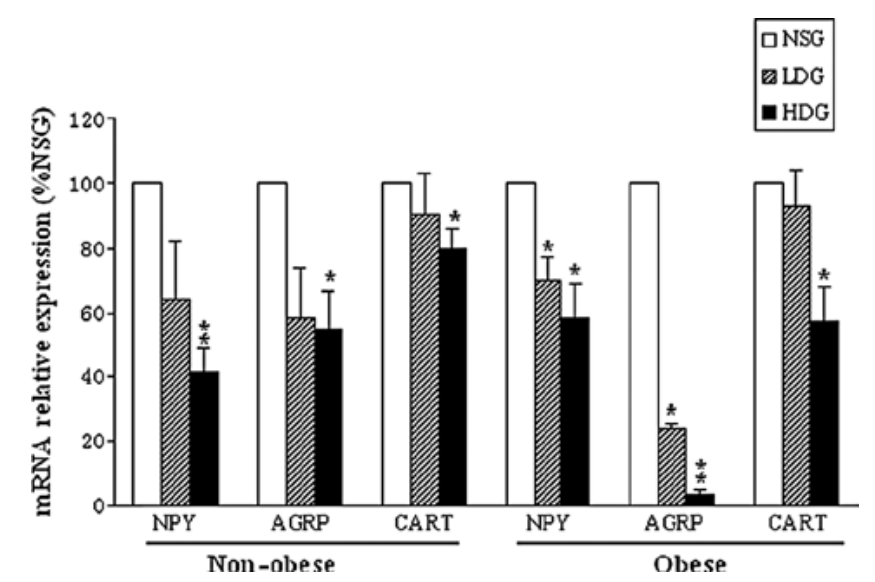

Figure 2. Effect of GC on NPY, AGRP and CART gene expression in the hypothalamus of rats. Non-obese rats (NSG, $n=12$; LDG and HDG, $n=13$ ), Obese rats (NSG and LDG, $n=13$; HDG, $n=14$ ). NSG, normal saline group; LDG, low-dose glucocorticoid group ( $5 \mathrm{mg} / \mathrm{kg} / \mathrm{day})$; HDG, high-dose glucocorticoid group $(15 \mathrm{mg} / \mathrm{kg} /$ day). Data are expressed as the means \pm SEM of the NSG. ${ }^{*} \mathrm{p}<0.05,{ }^{* *} \mathrm{p}<0.01$.

Cumulative food intake in the HDG rats became significantly less than that of the NSG rats on the 16th day after treatment for the non-obese rats $(380.00 \pm 35.00$ vs. $430.42 \pm 57.53 \mathrm{~g}, \mathrm{t}=2.31$, $\mathrm{p}<0.05$ ) (Fig. 1C). For the obese rats, cumulative food intake decreased earlier than that in the non-obese rats, which began on the 10th day after treatment $(232.79 \pm 21.45$ vs. $257.15 \pm 38.66 \mathrm{~g}, \mathrm{t}=2.42, \mathrm{P}<0.05)$ (Fig. 1D) After low-dose GC treatment, cumulative food intake did not exhibit any significant difference compared to the NSG rats $(\mathrm{p}>0.05)$.

GC treatment elevates serum glucose and insulin concentrations resulting in dislipidemia. Serum glucose, triglycerides, total cholesterol, low-density lipoprotein and insulin increased $(\mathrm{p}<0.01)$, while high-density lipoprotein decreased significantly $(\mathrm{p}<0.001)$ after the 20-day continuous high-dose GC treatment compared to rats in the NSG for both the non-obese and obese rats (Table II).

For the non-obese rats, after 20 continuous days of lowdose GC treatment, total cholesterol was not significantly different than total cholesterol in the NSG rats $(p>0.05)$, while serum glucose, insulin, triglyceride and low-density lipoprotein were significantly elevated compared to the control $(\mathrm{p}<0.05)$. However, in the obese rats, after low-dose GC treatment, triglycerides were not significantly different compared to the rats in the NSG ( $>00.05$ ), while serum glucose, insulin, total cholesterol and low-density lipoprotein were significantly elevated $(\mathrm{p}<0.05)$.

GC treatment decreases the NPY, AGRP and CART gene expression levels in the hypothalamus of the rats. After 20 continuous days of high-dose GC treatment, mRNA gene expression levels of the appetite peptides NPY, AGRP and CART decreased to $58 \pm 11,3 \pm 1.7$ and $57 \pm 11 \%$, respectively, compared to levels in the NSG for the obese rats; while in the non-obese rats, these levels dropped to $41 \pm 8,55 \pm 11$ and $80 \pm 6 \%$, respectively, compared to those of the NSG rats (Fig. 2).

However, after the 20-day continuous low-dose GC treatment, the mRNA expression levels of the appetite peptides NPY and AGRP and CART decreased to $70 \pm 7,24 \pm 1.5$ and $93 \pm 11 \%$, respectively, compared to levels in the NSG for the obese rats. For the non-obese rats, these levels declined to $64 \pm 18,58 \pm 16$ and $90 \pm 13 \%$, respectively, compared to those in the NSG (Fig. 2).

We observed that after high-dose GC treatment, mRNA gene expression levels of the orexigenic neuropeptides NPY and AGRP were lower than levels in the NSG(p<0.05), and also for the mRNA expression level of the anorectic neuropeptide CART, in both the non-obese and obese rats (Fig. 2).

There were certain differences in the appetite-regulation peptide expression patterns between the obese and non-obese rats after low-dose GC treatment (Fig. 2). The NPY, AGRP and CART mRNA expression levels did not exhibit any significant differences compared to the NSG for the non-obese rats. For 
the obese rats after low-dose GC treatment, the NPY and AGPR mRNA expression levels were significantly decreased compared to those of the NSG rats $(\mathrm{p}<0.05)$, while CART mRNA did not exhibit a significant decrease.

\section{Discussion}

The present data revealed that a 20-day continuous intraperitoneal infusion of the synthetic glucocorticoid, hydrocortisone sodium succinate, to non-obese and obese rats decreased their body weight and food intake. Twenty-day consecutive intraperitoneal injection of GC at a dose of 5 and $15 \mathrm{mg} /$ $\mathrm{kg}$ both decreased weight and food intake in the rats (180$200 \mathrm{~g}$ ), significantly at the latter dose. It was also found that weight and food intake decreased earlier and the extent of the decrease was markedly greater in the HDG compared to the LDG rats. This effect of GC on food intake and weight in rats is in agreement with previous studies. De Vos et al treated rats once daily for 20 days with a subcutaneous pharmacological dose of hydrocortisone (1, 10 and $100 \mu \mathrm{g} / \mathrm{g} /$ day $)$ and reported that glucocorticoids caused a decrease in body weight and food consumption (21). Zakrzewska et al (19) found that intraperitoneal infusion of dexamethasone (Dex; $0.025 \mathrm{mg} / \mathrm{kg}$ / day) for 3 days in normal rats resulted in a significant decrease in food intake and body weight. Konno et al (22) reported that a 10-day subcutaneous injection of Dex ( $2 \mathrm{mg} / \mathrm{kg} / \mathrm{day})$ resulted in a significant decrease in weight and food intake in Wistar rats. Coll et al (23) reported a significant decrease in body weight and length in Pomc $^{-/-}$mice after receiving cortisosterone-supplemented drinking water $(25 \mu \mathrm{g} / \mathrm{ml}$ final concentration). These results indicate that GCs have an inhibitory effect on body weight and food intake in rodents.

However, divergent findings have been reported on the effect of GCs on body weight and food intake. Zakrzewska et al (19) found that i.c.v. infusion of Dex $(0.025 \mathrm{mg} / \mathrm{kg} /$ day $)$ for 3 days in normal rats resulted in a significant increase in food intake relative to vehicle-infused control animals. Germano et al (24) reported weight and daily food intake were significantly reduced 14 days after adrenalectomy (ADX) compared to a sham group. Devenport et al found that continuous infusion of corticosterone yielded a bitonic dose-response curve for body weight and feeding efficiency (25). The effects appear to occur at approximately $1 \mu \mathrm{g} / \mathrm{dl}$, and reached peak anabolic effect at approximately $2 \mu \mathrm{g} / \mathrm{dl}$, then decreased with the increase in serum levels.

In the present study NPY, AGRP and CART mRNA expression was evaluated in the hypothalamus in non-obese and obese rats after GC treatment using real-time quantitative PCR. At the end of the experiment, NPY and AGRP mRNA expression had significantly decreased in the obese rats after 20 consecutive days of a $5 \mathrm{mg} / \mathrm{kg} / \mathrm{day} \mathrm{GC}$ injection, while no significant decrease was observed in non-obese rats $(5 \mathrm{mg} / \mathrm{kg} /$ day). The mRNA expression of the orexigenic neuropeptides NPY and AGRP decreased in both the non-obese and obese rats after 20 consecutive days of $15 \mathrm{mg} / \mathrm{kg} /$ day $\mathrm{GC}$ injection. This result may account, at least in part, for the decreased food intake and weight after GC treatment in rats, since the orexigenic neuropeptides NPY and AGRP are important in promoting appetite and maintaining energy homeostasis. The finding that GC treatment decreased NPY and AGRP mRNA expression in the hypothalamus of non-obese and obese rats is consistent with the result that intraperitoneal Dex infusion $(0.025 \mathrm{mg} / \mathrm{kg} /$ day for 3 days) resulted in a significant decrease in the arcuate nucleus NPY levels (19). However, there are several contradictory reports. Konno et al reported a higher NPY mRNA level in the hypothalamus of Wistar rats after 10 consecutive days of a subcutaneous injection of Dex (2 mg/ $\mathrm{kg} /$ day) (22). Makimura et al (26) found that ADX completely blocked the elevation of NPY and AGRP mRNA in diabetic mice. Hypothalamic AGRP mRNA was reportedly induced by a GC implant, whereas the NPY mRNA was not significantly influenced. In addition, Drazen et al (27) found that ADX altered the sensitivity of the central melanocortin system to the effect of the melanocortin antagonist AGRP, with the orexigenic effect of this peptide being absent in ADX rats, but restored with GC supplementation $(2.7 \mathrm{mg} / \mathrm{ml}$ corticosterone in their drinking water).

CART is co-localized within the majority of proopiomelanocortin (POMC) neurons in the hypothalamus and inhibits food intake. CART expression is regulated by GCs, and CART, in turn, appears to regulate hypothalamic-pituitary-adrenal (HPA) axis activity via a direct effect on corticotrophinreleasing hormone (CRH) signaling (28-31). Germano et al reported that Wistar rats following long-term ADX displayed a decrease in CART expression in the hypothalamus under ad libitum feeding conditions (24). Hunter et al reported that ADX in rats significantly reduced CART expression in the hypothalamus and this effect was blocked by corticosterone (400 $\mu \mathrm{g} / \mathrm{ml}$ in their drinking water) (32). However, we found that GC treatment decreased CART mRNA expression in the hypothalamus in both non-obese and obese rats.

There is a GC response element upstream of the rat NPY gene, and GC receptors have been shown to be highly expressed in all NPY-containing neurons in the arcuate nucleus (33-35). Since all arcuate AGRP neurons express NPY, there are GC receptors in AGRP neurons (11). We believe that centrally administered GCs may exert a direct effect on appetite peptide neurons, while peripherally administered GCs exert a more complex and indirect effect.

Arc neurons, including POMC and AGRP/NPY neurons, have been shown to respond to changes in ambient glucose concentrations, either as being glucose excited (increase in glucose leads to increase in firing) or glucose inhibited (increase in glucose leads to decrease in firing) (36-38).

Arumugam et al found that glucose deprivation $(2 \mathrm{mmol} / \mathrm{l})$ stimulated an increase in NPY mRNA levels in INS-1 cells, since INS-1 cells have certain functional similarities with hypothalamic neurons (39). Conversely, glucose excess (11 mmol/l) inhibited expression of NPY mRNA, but transiently increased the expression of CART. They also found that $1 \mu \mathrm{M}$ Dex stimulated a 5.2-fold increase in NPY mRNA, while it reduced the levels of CART mRNA by $65 \%$. Singh et al demonstrated that the maternal diabetic state associated with fetal hyperglycemia in the absence of fetal insulin changes led to a $40 \%$ decline in fetal brain NPY mRNA and a $50 \%$ decline in protein levels (40).

Circulating insulin may regulate food intake and body weight as the result of its effects in the central nervous system (CNS). Circulating insulin delivery into the CNS is facilitated by an insulin receptor-mediated transport process (41). Insulin 
was found to reduce food intake and body weight in a dosedependent manner when administered directly into the CNS (42). Central insulin administration attenuates the increase in hypothalamic NPY mRNA levels associated with both fasting and insulin-deficiency diabetes (43), and insulin has been shown to transport across the endothelial cells of the bloodbrain barrier (41). Combined with the evidence that receptors for insulin are concentrated in the ARC $(44,45)$, these results suggest that the hypothalamic NPY system is normally inhibited by the negative feedback provided by insulin. In our study, the increase in the serum insulin level after GC treatment may in part explain the decrease in food intake and body weight in rats. In another study, Sahu et al reported that in the adult rat, streptozotocin-induced diabetes associated with hyperglycemia and hypoinsulinemia caused an increase in hypothalamic NPY levels (46).

In our study, we found that 20 consecutive days of intraperitoneal injection of GC at doses of 5 and $15 \mathrm{mg} / \mathrm{kg}$ led to hyperglycemia and hyperinsulinemia in obese and non-obese rats, and we think that this may be part of the reason for the decrease in NPY in the hypothalamus.

We suspect that hyperglycemia and hyperinsulinemia exert a synergistic effect on the inhibition of NPY expression in the hypothalamus after long-term GC treatment. Short-term GC treatment is not always accompanied by hyperglycemia and hyperinsulinemia, which may be the reason for the contradictory effects on NPY expression between long- and short-term GC treatments.

In normal rats, leptin administration blunts the effect of fasting by increasing the hypothalamic NPY mRNA levels (44). Systemic administration of leptin inhibits NPY gene overexpression through a specific action in the arcuate nucleus and exerts a hypoglycemic action that is partly independent of its weight-reducing effects (47). A majority of both NPY/ AGRP and POMC/CART neurons have been found to coexpress leptin receptors $(48,49)$.

Ma et al found that the effects of leptin depend on the ambient glucose concentration (50). When glucose is low $(5 \mathrm{mM}$ or less), AGRP neurons are more important for mediating the anorectic effects of leptin than POMC cells. However, at high glucose concentrations (11 mM), activation of POMC cells may contribute to the appetite-suppressing effects of leptin.

De Vos et al treated rats once daily for 20 days with a subcutaneous pharmacological dose of hydrocortisone (1, 10 and $100 \mu \mathrm{g} / \mathrm{g} / \mathrm{day}$ ), and found that GCs induce overexpression in rat adipose tissue dose-dependently (21). The glucosedependent effects of leptin may also help explain why GCs display a bitonic dose-response curve for body weight and feeding efficiency. Short-term or low-dose GC treatment may increase the serum glucose level slightly, and in this condition leptin may exert an orexigenic effect by inhibiting POMC function, while long-term, high-dose GC treatment always increases the serum glucose level significantly and excites the leptin anorexigenic effect.

We presume that the difference between our study and previous reports may be due to the low-dose GC and/or the short-term GC treatment increasing NPY and AGRP mRNA expression through a direct effect. However, high-dose GC and/or long-term GC treatment resulted in an inhibitory effect on NPY and AGRP mRNA expression, which may be an indirect effect of GCs. It is known that hyperglycemia, lipid metabolic disturbance, hyperinsulinemia and hyperleptinemia are associated with lower expression levels of NPY and AGRP mRNA. High-dose GC and/or long-term GC treatment may induce hyperglycemia, lipid metabolic disturbance, hyperinsulinemia and hyperleptinemia first, and these metabolic disturbances inhibit NPY and AGRP mRNA expression in the hypothalamus. In the present study, we found that weight and food intake decreased earlier, and the extent of the decrease being more obvious after high- than low-dose GC treatment is also consistent with this hypothesis. High-dose GC treatment causes earlier and more serious glucose and lipid disturbances, which could result in a decrease in NPY and AGRP mRNA expression, followed by decreased food intake and weight.

The current understanding of the central appetite regulating NPY, AGRP and CART signaling pathways is not able to explain the decrease in CART expression, and the decrease in food intake and weight, concurrently after GC treatment. There is still much more to explore with regards to how GCs affect appetite and body weight. Whether the dosage, administration route (i.c.v. or intraperitoneal injection) or duration of treatment is responsible for the contradictory outcome of appetite and body weight change after GC treatment, or via some as yet unidentified mechanism or target, remains to be determined.

In conclusion, GC treatment in rat decreased appetite and body weight, induced apparent glucolipid metabolic disturbances and hyperinsulinemia, while down-regulated orexigenic neuropeptides NPY and AGRP and anorexigenic neuropeptide CART mRNA expression levels in the hypothalamus in rats. High-dose GC and/or long-term GC treatment may exert an inhibitory effect on body weight, food intake and appetite peptide expression in the hypothalamus through an indirect effect secondary to metabolic changes. Elucidation of the mechanism requires further study.

\section{Acknowledgements}

This study was funded by grants to Jian-Hua Shi from the National Nature Science Foundation of China (30440026), to Feng-Ling Chen from the National Nature Science Foundation of China (30870954) and the Shanghai Commission for Science and Technology (07ZR14071). The authors thank J.F. Tang of the Shanghai Institute of Endocrinology for the ELISA technique in this study. Pacific Edit reviewed the manuscript prior to submission.

\section{References}

1. Stellar E: The physiology of motivation. 1954. Psychol Rev 101: 301-311, 1994.

2. Bi S, Scott KA, Hyun J, Ladenheim EE and Moran TH: Running wheel activity prevents hyperphagia and obesity in Otsuka LongEvans Tokushima Fatty rats: role of hypothalamic signaling. Endocrinology 146: 1676-1685, 2005.

3. Kohno D, Gao HZ, Muroya S, Kikuyama S and Yada T: Ghrelin directly interacts with neuropeptide-Y-containing neurons in the rat arcuate nucleus: $\mathrm{Ca}^{2+}$ signaling via protein kinase $\mathrm{A}$ and $\mathrm{N}$-type channel-dependent mechanisms and cross-talk with leptin and orexin. Diabetes 52: 948-956, 2003.

4. Shintani M, Ogawa Y, Ebihara K, Aizawa-Abe M, Miyanaga F, Takaya K, Hayashi T, Inoue G, Hosoda K, Kojima M, Kangawa K and Nakao K: Ghrelin, an endogenous growth hormone secretagogue, is a novel orexigenic peptide that antagonizes leptin action through the activation of hypothalamic neuropeptide Y/ Y1 receptor pathway. Diabetes 50: 227-232, 2001. 
5. Tebbe JJ, Tebbe CG, Mronga S, Ritter M and Schäfer MK: Central neuropeptide $Y$ receptors are involved in 3rd ventricular ghrelin-induced alteration of colonic transit time in conscious fed rats. BMC Gastroenterol 5: 5, 2005.

6. Hohmann JG, Teklemichael DN, Weinshenker D, Wynick D, Clifton DK and Steiner RA: Obesity and endocrine dysfunction in mice with deletions of both neuropeptide $\mathrm{Y}$ and galanin. Mol Cell Biol 24: 2978-2985, 2004

7. Raposinho PD, Pedrazzini T, White RB, Palmiter RD and Aubert ML: Chronic neuropeptide Y infusion into the lateral ventricle induces sustained feeding and obesity in mice lacking either Npy1r or Npy5r expression. Endocrinology 145: 304-310, 2004.

8. Baran K, Preston E, Wilks D, Cooney GJ, Kraegen EW and Sainsbury A: Chronic central melanocortin-4 receptor antagonism and central neuropeptide-Y infusion in rats produce increased adiposity by divergent pathways. Diabetes 51: 152-158, 2002.

9. Fekete C, Sarkar S, Rand WM, Harney JW, Emerson CH, Bianco AC and Lechan RM: Agouti-related protein (AGRP) has a central inhibitory action on the hypothalamic-pituitarythyroid (HPT) axis; comparisons between the effect of AGRP and neuropeptide $\mathrm{Y}$ on energy homeostasis and the HPT axis. Endocrinology 143: 3846-3853, 2002.

10. Bannon AW, Seda J, Carmouche M, Francis JM, Norman MH Karbon B and McCaleb ML: Behavioral characterization of neuropeptide Y knockout mice. Brain Res 868: 79-87, 2000.

11. Broberger C, Johansen J, Johansson C, Schalling M and Hökfelt T: The neuropeptide Y/agouti gene-related protein (AGRP) brain circuitry in normal, anorectic, and monosodium glutamatetreated mice. Proc Natl Acad Sci USA 95: 15043-15048, 1998.

12. Hahn TM, Breininger JF, Baskin DG and Schwartz MW: Coexpression of Agrp and NPY in fasting-activated hypothalamic neurons. Nat Neurosci 1: 271-272, 1998.

13. Ollmann MM, Wilson BD, Yang YK, Kerns JA, Chen Y, Gantz I and Barsh GS: Antagonism of central melanocortin receptors in vitro and in vivo by agouti-related protein. Science 278 : $135-138,1997$.

14. Shutter JR, Graham M, Kinsey AC, Scully S, Lüthy R and Stark KL: Hypothalamic expression of ART, a novel gene related to agouti, is up-regulated in obese and diabetic mutant mice. Genes Dev 11: 593-602, 1997.

15. Tang-Christensen M, Vrang N, Ortmann S, Bidlingmaier M, Horvath TL and Tschöp M: Central administration of ghrelin and agouti-related protein (83-132) increases food intake and decreases spontaneous locomotor activity in rats. Endocrinology 145: 4645-4652, 2004.

16. Marsh DJ, Miura GI, Yagaloff KA, Schwartz MW, Barsh GS and Palmiter RD: Effects of neuropeptide Y deficiency on hypothalamic agouti-related protein expression and responsiveness to melanocortin analogues. Brain Res 848: 66-77, 1999.

17. Makimura H, Mizuno TM, Mastaitis JW, Agami R and Mobbs CV: Reducing hypothalamic AGRP by RNA interference increases metabolic rate and decreases body weight without influencing food intake. BMC Neurosci 3: 18, 2002.

18. Small CJ, Kim MS, Stanley SA, Mitchell JR, Murphy K, Morgan DG, Ghatei MA and Bloom SR: Effects of chronic central nervous system administration of agouti-related protein in pair-fed animals. Diabetes 50: 248-254, 2001.

19. Zakrzewska KE, Cusin I, Stricker-Krongrad A, Boss O, Ricquier D, Jeanrenaud B and Rohner-Jeanrenaud F: Induction of obesity and hyperleptinemia by central glucocorticoid infusion in the rat. Diabetes 48: 365-370, 1999.

20. Chen HL and Romsos DR: A single intracerebroventricular injection of dexamethasone elevates food intake and plasma insulin and depresses metabolic rates in adrenalectomized obese (ob/ob) mice. J Nutr 125: 540-545, 1995.

21. De Vos P, Saladin R, Auwerx J and Staels B: Induction of ob gene expression by corticosteroids is accompanied by body weight loss and reduced food intake. J Biol Chem 270: 15958-15961, 1995.

22. Konno J, Yoshida S, Ina A, Ohmomo H, Shutoh F, Nogami H and Hisano S: Upregulated expression of neuropeptide $\mathrm{Y}$ in hypothalamic-pituitary system of rats by chronic dexamethasone administration. Neurosci Res 60: 259-265, 2008.

23. Coll AP, Challis BG, López M, Piper S, Yeo GS and O'Rahilly S: Proopiomelanocortin-deficient mice are hypersensitive to the adverse metabolic effects of glucocorticoids. Diabetes 54: 2269-2276, 2005.
24. Germano CM, de Castro M, Rorato R, Laguna MT, Antunes-Rodrigues J, Elias CF and Elias LL: Time course effects of adrenalectomy and food intake on cocaine- and amphetamineregulated transcript expression in the hypothalamus. Brain Res 1166: 55-64, 2007.

25. Devenport L, Knehans A, Sundstrom A and Thomas T: Corticosterone's dual metabolic actions. Life Sci 45: 1389-1396, 1989.

26. Makimura H, Mizuno TM, Isoda F, Beasley J, Silverstein JH and Mobbs CV: Role of glucocorticoids in mediating effects of fasting and diabetes on hypothalamic gene expression. BMC Physiol 3: 5, 2003.

27. Drazen DL, Wortman MD, Schwartz MW, Clegg DJ, van Dijk G, Woods SC and Seeley RJ: Adrenalectomy alters the sensitivity of the central nervous system melanocortin system. Diabetes 52: 2928-2934, 2003.

28. Balkan B, Koylu E, Pogun S and Kuhar MJ: Effects of adrenalectomy on CART expression in the rat arcuate nucleus. Synapse 50: 14-19, 2003.

29. Vrang N, Larsen PJ, Tang-Christensen M, Larsen LK and Kristensen P: Hypothalamic cocaine-amphetamine regulated transcript (CART) is regulated by glucocorticoids. Brain Res 965: 45-50, 2003.

30. Vicentic A, Dominguez G, Hunter RG, Philpot K, Wilson M and Kuhar MJ: Cocaine- and amphetamine-regulated transcript peptide levels in blood exhibit a diurnal rhythm: regulation by glucocorticoids. Endocrinology 145: 4119-4124, 2004.

31. Wittmann G, Liposits Z, Lechan RM and Fekete C: Origin of cocaine- and amphetamine-regulated transcript-containing axons innervating hypophysiotropic corticotropin-releasing hormone-synthesizing neurons in the rat. Endocrinology 146: 2985-2991, 2005.

32. Hunter RG, Bellani R, Bloss E, Costa A, Romeo RD and McEwen BS: Regulation of CART mRNA by stress and corticosteroids in the hippocampus and amygdala. Brain Res 1152: 234-240, 2007.

33. Misaki N, Higuchi H, Yamagata K and Miki N: Identification of glucocorticoid responsive elements (GREs) at far upstream of rat NPY gene. Neurochem Int 21: 185-189, 1992.

34. Cintra A, Fuxe K, Solfrini V, Agnati LF, Tinner B, Wikström AC, Staines W, Okret S and Gustafsson JA: Central peptidergic neurons as targets for glucocorticoid action. Evidence for the presence of glucocorticoid receptor immunoreactivity in various types of classes of peptidergic neurons. J Steroid Biochem Mol Biol 40: 93-103, 1991

35. Härfstrand A, Cintra A, Fuxe K, Aronsson M, Wikström AC, Okret S, Gustafsson JA and Agnati LF: Regional differences in glucocorticoid receptor immunoreactivity among neuropeptide Y immunoreactive neurons of the rat brain. Acta Physiol Scand 135: 3-9, 1989.

36. Burdakov D, Luckman SM and Verkhratsky A: Glucose-sensing neurons of the hypothalamus. Philos Trans R Soc Lond B Biol Sci 360: 2227-2235, 2005 .

37. Claret M, Smith MA, Batterham RL, et al: AMPK is essential for energy homeostasis regulation and glucose sensing by POMC and AgRP neurons. J Clin Invest 117: 2325-2336, 2007.

38. Parton LE, Ye CP, Coppari R, et al: Glucose sensing by POMC neurons regulates glucose homeostasis and is impaired in obesity. Nature 449: 228-232, 2007.

39. Arumugam R, Fleenor D and Freemark M: Lactogenic and somatogenic hormones regulate the expression of neuropeptide $\mathrm{Y}$ and cocaine- and amphetamine-regulated transcript in rat insulinoma (INS-1) cells: interactions with glucose and glucocorticoids. Endocrinology 148: 258-267, 2007.

40. Singh BS, Westfall TC and Devaskar SU: Maternal diabetes-induced hyperglycemia and acute intracerebral hyperinsulinism suppress fetal brain neuropeptide Y concentrations. Endocrinology 138: 963-969, 1997

41. Baura GD, Foster DM, Porte D Jr, Kahn SE, Bergman RN, Cobelli C and Schwartz MW: Saturable transport of insulin from plasma into the central nervous system of dogs in vivo. A mechanism for regulated insulin delivery to the brain. J Clin Invest 92: 1824-1830, 1993

42. Chavez M, Seeley RJ and Woods SC: A comparison between effects of intraventricular insulin and intraperitoneal lithium chloride on three measures sensitive to emetic agents. Behav Neurosci 109: 547-550, 1995.

43. Sipols AJ, Baskin DG and Schwartz MW: Effect of intracerebroventricular insulin infusion on diabetic hyperphagia and hypothalamic neuropeptide gene expression. Diabetes 44: 147-151, 1995. 
44. Schwartz MW, Seeley RJ, Campfield LA, Burn P and Baskin DG: Identification of targets of leptin action in rat hypothalamus. J Clin Invest 98: 1101-1106, 1996.

45. Baskin DG, Wilcox BJ, Figlewicz DP and Dorsa DM: Insulin and insulin-like growth factors in the CNS. Trends Neurosci 11: 107-111, 1988.

46. Sahu A, Sninsky CA, Phelps CP, Dube MG, Kalra PS and Kalra SP: Neuropeptide Y release from the paraventricular nucleus increases in association with hyperphagia in streptozotocin-induced diabetic rats. Endocrinology 131: 2979-2985, 1992.

47. Schwartz MW, Baskin DG, Bukowski TR, et al: Specificity of leptin action on elevated blood glucose levels and hypothalamic neuropeptide Y gene expression in ob/ob mice. Diabetes 45: 531-535, 1996.
48. Baskin DG, Breininger JF and Schwartz MW: Leptin receptor mRNA identifies a subpopulation of neuropeptide Y neurons activated by fasting in rat hypothalamus. Diabetes 48: 828-833, 1999.

49. Cheung CC, Clifton DK and Steiner RA: Proopiomelanocortin neurons are direct targets for leptin in the hypothalamus. Endocrinology 138: 4489-4492, 1997.

50. Ma X, Zubcevic L and Ashcroft FM: Glucose regulates the effects of leptin on hypothalamic POMC neurons. Proc Natl Acad Sci USA 105: 9811-9816, 2008. 